\title{
Controlling the farmer: colonial and post- colonial irrigation interventions in Africa
}

\author{
MAURITS W. ERTSEN *
}

"I declare it's marked out just like a large chess-board!" Alice said at last. "There ought to be some men moving about somewhere - and so there are!" she added in a tone of delight, and her heart began to beat quickly with excitement as she went on. "It's a great huge game of chess that's being played - all over the world - if this is the world at all, you know. Oh, what fun it is! How I wish I was one of them! I wouldn't mind being a Pawn, if only I might join - though of course I should like to be a

Queen, best."

Lewis Carroll, Through the looking glass, 142-143.

\begin{abstract}
Aiming at full control over farmer actions was a shared characteristic of colonial irrigation engineering approaches. However, the way control was sought in African irrigation projects was different from Asian colonies. This paper traces the origins of colonial approaches to irrigation development in Africa and the continuities between colonial and post-colonial approaches. The Kano River Project in Nigeria, part of a larger irrigation development program from the late 1960s and early 1970s, serves as a typical example of a post-colonial irrigation system in which engineers drew upon colonial experiences. The Dutch engineers responsible for developing the system applied technologies from the Netherlands East Indies to regulate water flows in the system. At the same time, they engaged in a debate on how to organize farmers in the project to ensure efficient and rational use of water in irrigated farming. They joined project managers in viewing strong control over farmer production - a central feature of African colonial irrigation projects - as key to success. However, given the social conditions in the Kano area, particularly landownership, this strong control proved difficult to realize.
\end{abstract}

Keywords: Irrigation, Africa, Kano River, Nigeria, Land tenure, colonial irrigation, postcolonial irrigation.

Disciplines: Engineering, hydrology, water management, water history.

Senior lecturer, Water Resources Management, Department of Civil Engineering and Geosciences, Delft University of Technology, PO Box 5048, 2600 GA Delft, the Netherlands, tel + 31 (0) 1527 87423, fax + 31 (0) 152785559 , http:// www.wrm.tudelft.n1, m.w.ertsen@tudelft.n1 


\section{Introduction}

The development of water resources in Africa was a central concern for both colonial and post-colonial governments. Water development programs have included dams for electricity production and flood control, purification facilities for drinking water, the construction of piped supplies, and extensive irrigation projects. Whether designed by engineers working for the colonial power or the post-colonial state, all of these projects sought to control the flow of water for the purpose of economic development. From the late 1960s to the early 1970s, engineers in Northern Nigeria designed and implemented the Kano River Project (KRP). Part of a larger irrigation development program, the KRP promoted irrigation as a means to increase wheat production, provide protection from drought, and modernize the region's rural areas.

In the design process, Dutch engineers proposed to apply Begemann gates in order to control the project's water levels (Brouwer 1987; see figure 1). Named after the Dutch engineer S.H.A. Begemann, the technology originated in the Netherlands East Indies. There engineers introduced the automatic gates to replace the stop log gates used by local farmers which required the manual labor of the lower Javanese irrigation personnel. In this way, engineers were able to control the flow of water with a limited amount of staff time.

As colonial rule gave way to independence in the late 1950s and 1960 s, African governments requested that international development institutions and consultants assist in rural development efforts. Working within the new framework of development cooperation, foreign irrigation engineers developed schemes based upon the well-known design practices of their respective colonial irrigation approaches (Ertsen 2007).

The experiences of Dutch engineers with the Begemann gate in Asia influenced the technical approach they took to irrigation projects in Africa. Dutch engineers working on the KRP drew upon this technology to control the water flows. However, they worked within a different social, political, and environmental context. Kano was different from the Netherlands East Indies in terms of its geography, climate and farming systems.

Furthermore, responsibilities and roles of farmers and scheme management were defined differently than in typical irrigation systems in the East Indies. As a result, the ways engineers sought to incorporate farmer actions in the irrigation system invariably differed from the way farmer involvement was defined and achieved in the Netherlands East Indies. The transference of irrigation technologiessuch as the Begemann gate-proved easier than that of the management structures. 


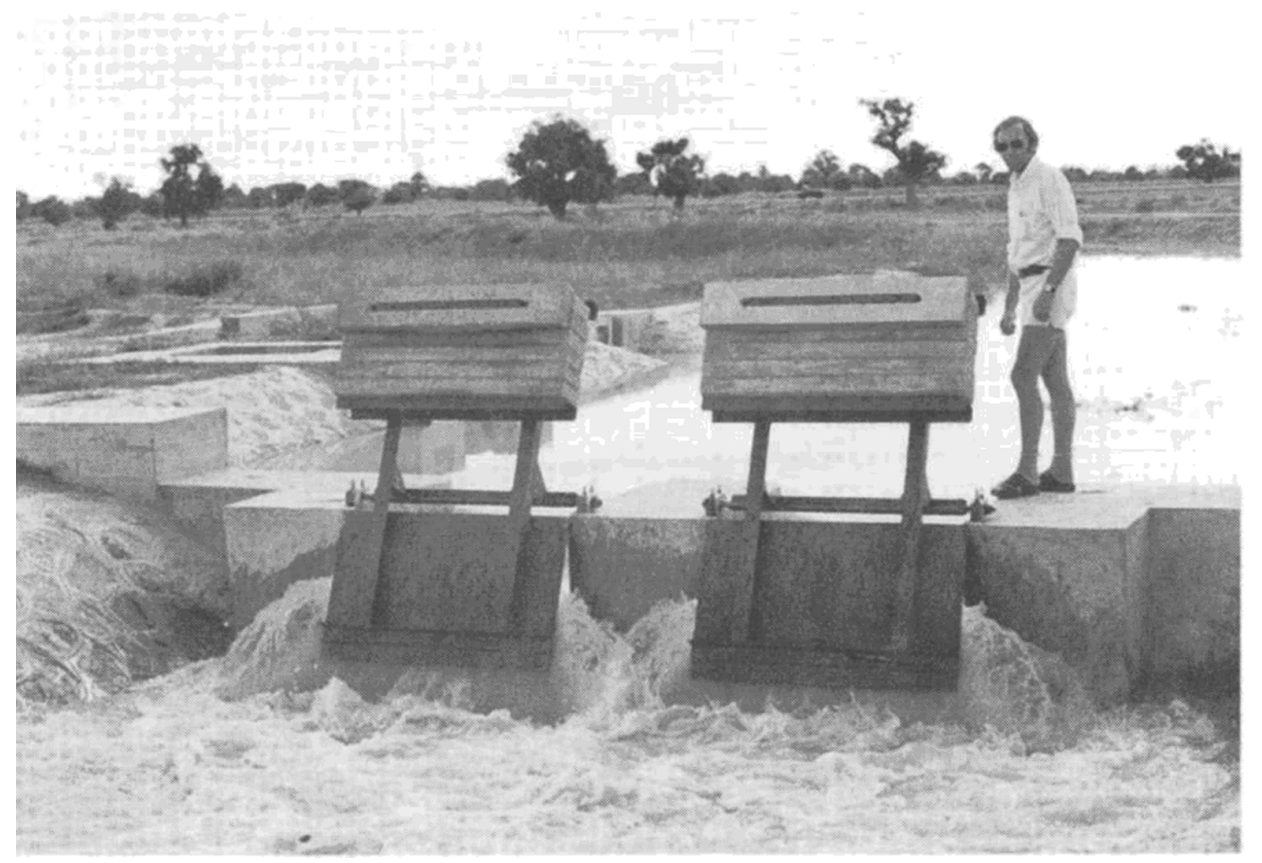

Figure 1. Begemann Gates in the Kano River Project. Source: Private archives of R. Brouwer

Within the KRP, Dutch engineers sought full control over all aspects of agricultural production including water control, water use, cropping strategies and pesticide use. In contrast, in the Netherlands East Indies engineers were aiming for full control over the water system so as to accommodate agricultural production (Ertsen 2006a). Farmers in the Netherlands East Indies, however, were not free to do whatever they wanted for they too had to adapt to colonial rule and colonial water distribution, and irrigation personnel did attempt to change farmers' cropping strategies to some extent. The approach KRP managers took to control farmers in Nigeria in the 1970s should be examined in the context of an established, colonial perspective on African irrigation. While aiming at control over farmers in itself may be a shared characteristic of many colonial irrigation engineering approaches, the way control was sought in African colonies was different from the former Asian colonies (Ertsen 2006b). British and Dutch colonial irrigation managers in Asia did not attempt to completely control production processes. For example, in Britishruled India, farmers were often landowners, or at least not tenants of an irrigation agency. Moreover, in the Netherlands East Indies the colonial government planned settlement schemes in the 1930s which treated farmers as the projects' future owners. 
In contrast, colonial irrigation schemes in Africa focused on altering farmers' actions through imposed production regimes. Farming communities were expected (and often forced) to cultivate exactly what the colonial management prescribed. Farmers on the African schemes were tenants of the irrigation agency, not landowners. On settlement schemes, colonial managers presented African tenants as having no relevant history in the area or, in some cases, the region itself as devoid of a legitimate history. To colonial engineers and project managers working in African colonies, "[t]he irrigated settlements came to be seen as vessels of modernity labouring through a sea of superstition" (Bolding 2004: 10).

Within the context of natural resource management, colonial policies in Africa have been extensively studied (Anderson 2002; Bassett \& Crummey 2003; Davis 2007; Hodge 2007; Tropp 2006). Scholars have examined the relationship between colonial policies and irrigation schemes such as the Gezira in the Sudan (Barnett 1977; Gaitskell 1959), the Office du Niger in Mali (Van Beusekom 1989 \& 2002; Spitz 1949) and North African projects (Poncet 1961; Préfol 1986; Swearingen 1984). Most of these studies, however, focus on one project or region. This paper departs from this approach by analyzing several irrigation efforts in different regions. Although some of the scholars mentioned above discuss continuities between colonial and post-colonial irrigation development, in general the scholarship on post-colonial irrigation development in Africa ignores colonial experiences. For example, in their 1973 book Chambers R. and Moris argue that the Mwea system in Kenya serves as an example for other irrigation projects in Africa that should be emulated. The authors never explicitly mention that British colonial administrators initially developed the project. Moreover, in their technical discussion on the differences between irrigation approaches between engineers and African farmers, they fail to examine the role of colonial irrigation approaches in shaping these approaches (Ubels \& Horst 1993).

Historians have established that modern engineering approaches have a colonial history (Ertsen 2006a \& 2007; Picon 2000 \& 2004). It is therefore impossible to regard these approaches as neutral. This does not imply at all that elements of these approaches are not feasible, as the example of teh Begemann gate illustrates. What it does imply, however, is the need to recognize the close relationship between colonial politics and engineering design and/or management. Such recognition is even more important when one realizes that next to artifacts and material objects useful for the fulfillment of needs, engineers and managers bring along a new societal reality. They change society with their designs-sometimes intentionally, sometimes not. The intention of colonial irrigation engineers was to alter colonial societies and production systems. One would expect 
(and hope) that the guiding ideas of today's engineers and managers have changed compared to colonial times. However, post-colonial ideas on proper irrigation development were influenced by colonial perceptions of good irrigation development practice. The following discussion focuses on how foreign managers, engineers and policy makers perceived irrigation development, and not on how African farmers viewed and responded to these initiatives (see for these responses Diemer 1990; Widgren \& Sutton 2004).

Using project reports written by the Dutch consultant NEDECO, monographs and the papers of former project employees (e.g. PalmerJones 1981; Chambers \& Morris 1973; Gaitskell 1959), and relevant secondary literature, this paper analyzes how colonial experiences in Asia and Africa influenced the irrigation efforts of Dutch engineers in the Kano region. After a brief discussion of Dutch and British engineering efforts in Asia, I turn to an examination of two influential British irrigation projects-the Gezira scheme in the Sudan (begun in the 1920s) and the Mwea irrigation scheme in Kenya (begun in the 1950s). Dutch engineers drew from the management approaches of these two schemes when designing the Kano River Project. Both schemes allowed for the control of farmers by the irrigation agency. However, KRP managers were frustrated in their attempts to control Nigerian farmers. In the post-colonial period, direct control over farmers proved to be impossible. With fewer options for strict control, post-colonial schemes like the KRP had to focus on building support structures for farmers instead of applying coercion and force.

\section{Colonial irrigation in Asia}

Irrigation technology has been an important factor in the expansion of wet rice farming in the Indonesian archipelago from early times. At the start of engaging with local irrigation, in the early $19^{\text {th }}$ century, the Dutch were impressed with Indonesian irrigation technologies and results. This changed when, in an attempt to increase their position within the early colonial state, engineers stressed that the (larger) indigenous irrigation structures were unsatisfactory. Developing irrigation structures using Dutch technology became an important instrument in the emancipation of engineers within the colonial bureaucracy. Colonial irrigation activities started on behalf of the European sugarcane cultivators in the $19^{\text {th }}$ century, but later efforts were also directed at supporting and improving the ricecultivation methods of the indigenous population (Ertsen 2006a).

Between 1830 and 1870, the colonial government required Javanese farmers to cultivate certain cash crops within the so-called Cultivation System ('Cultuurstelsel').' Governor General Van den Bosch introduced this system in an attempt to make a profit from the colony 
after the Java war (1825 - 1830). Two of the prescribed crops needed irrigation: sugarcane and (to a lesser extent) indigo. When several famines occurred during the 1840s and 1850s, colonial policy was passed to also support rice farming through irrigation development. In the second half of the $19^{\text {th }}$ century, forced cultivation was abandoned. Sugar-processing factories rented land from Javanese owners to grow sugarcane. In the context of the 1901 Ethical Policy, new measures had to improve the position of the Javanese population. The focus on economic profit from the colony was softened somewhat within the Ethical Policy, although measures dealing with irrigation, emigration and education still had to be checked for potential economic benefit. Dutch irrigation in the Netherlands East Indies had to keep a continuous balance between interests of the population (rice) and industry (sugarcane). As a result, a detailed irrigation distribution and management structure developed (Ertsen 2006a).

Dutch colonial water distribution policies contrast with policies of the British colonial administration in India. Irrigation systems in British India were primarily aimed at maximizing economic profit through an increased tax on irrigated land as opposed to dry land. Actual harvests were not taken into account. In contrast, the Dutch colonial administration levied taxes on actual harvests per unit of land. This coincided with the general Dutch colonial policy, which depended on labour instead of land. In response to severe famines, after 1860 the British introduced the concept of protective irrigation. Schemes were designed to provide small amounts of water to a large area: the goal was to provide enough to save food crops during drought (Bolding et al 1995). Adapting water delivery to changing demands in order to increase harvests was not desired; providing water to the land in many different situations was. After all, even in a colony, levying taxes without some guaranteed delivery of water was not done.

The irrigation systems on the sub-continent were large with long canals and many outlets. With British colonial rule relying on market forces rather than governmental planning, operation of the large irrigation systems had to be simple, run by as few people as possible and cheap. What the British were looking for was an irrigation system that would function without active management. The British were interested in a discharge structure, which could deliver a known, fixed flow to a known area without the need for regular adjustment. They called this structure a module. The first British systems in India used (non-modular) division structures (mainly gated pipes), but these were inadequate to realize the desired water distribution. This general

1 The termination of the arrangements of the Cultivation System differed per crop type and could last up to 1915. 
idea for a module was translated differently in different local contexts in the immense Indian colony. In the Bombay Agency, British engineers developed structures discharging a constant volume independent of changes in canal flow (Bolding et al. 1995); in the Punjab they developed a structure delivering a fixed proportion of the canal flow (Van Halsema 2002). The British irrigation approach employed the principle that 'water follows irrigated surface,' whereas the general guiding principle of the Dutch irrigation approach was that 'water follows irrigated crop.' This meant that the right amount of water should be distributed when the standing crop needed it. These policies were translated into specific design requirements for water distribution. In the East Indies, these were (1) adjustability of structures to manipulate water flows and (2) the possibility to measure water flows. As European engineers turned their attention to other regions of the world, these principles would influence irrigation development.

Figure 2. Gezira, Mwea and Kano irrigation systems in Africa. Source: http://z.about.com/d/geography/1/0/4/L/africa.jpg (accessed on 2 July 2008).

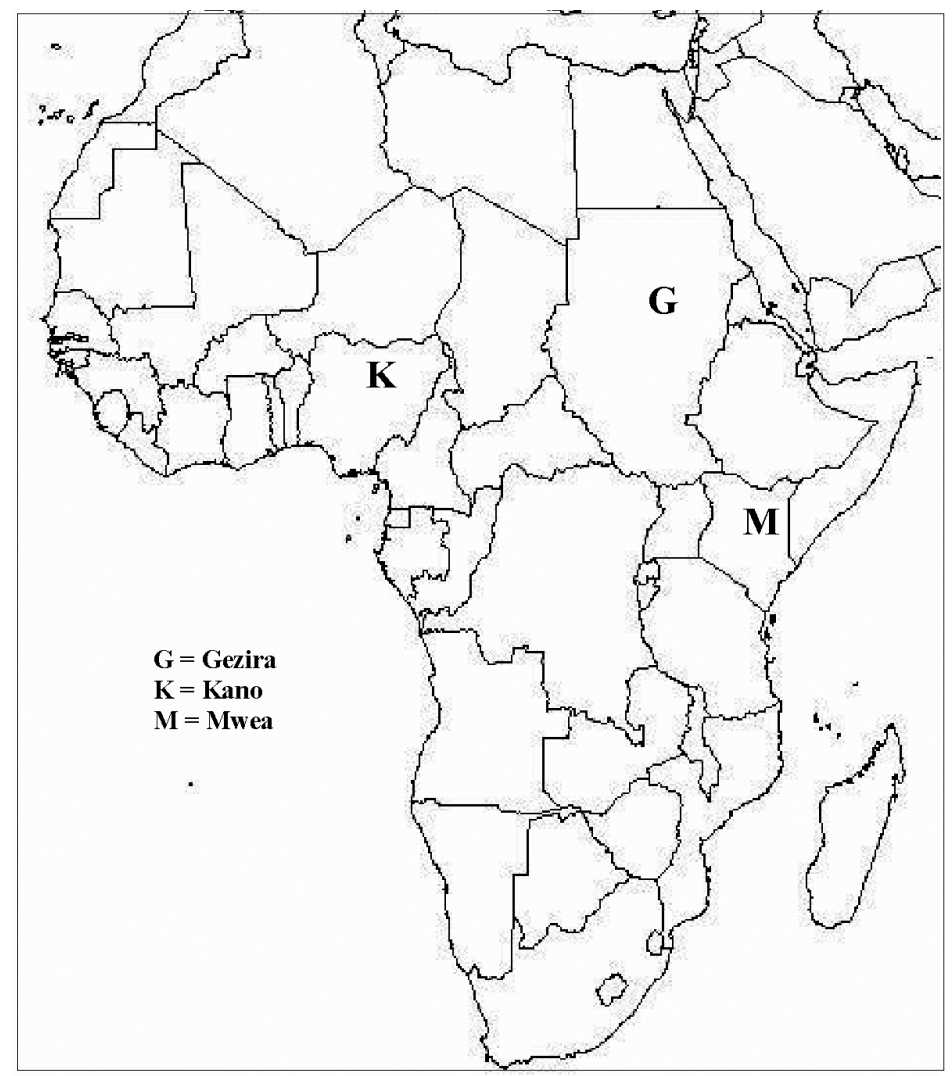




\section{The Gezira scheme, Sudan}

At the time that British and Dutch engineers were already working to develop irrigation in their Asian territories, colonial Africa was still relatively untouched by irrigation engineers. At the Berlin Conference in November 1884 colonial powers like France, Great Britain and Germany first met to settle their spheres of influence in Africa. By the early 1900s, particularly after the First World War, colonial administrations began directing more attention to the economic development of their colonies. Irrigation was perceived as a very good instrument to achieve both economic development and food production; many colonial irrigation efforts were aimed at combining profitable cash crops with food production.

After territorial disputes in Africa were settled, British colonial planners turned their attention to the creation of irrigation systems. During the early $20^{\text {th }}$ century, the Gezira Scheme in the Sudan became the most famous British irrigation project. The Scheme today covers an area of some 2.1 million feddans (one feddan $=0.42 \mathrm{ha}$ ) principally under gravity irrigation. Such a large area was not developed uncontested; irrigation development in the Gezira triangle of land between the Blue and the White Nile south of Khartoum was heavily debated, especially as Egypt wanted to assure its own supply of the precious Nile waters. Shortly after the turn of the $20^{\text {th }}$ century, in 1904, Sir William Garstin published the first overall plan for the control of the Nile Basin (Gaitskell 1959). Garstin had entered the Indian Public Works Department in 1872, and was one of the engineers who had been sent to Egypt in 1885 to direct important irrigation works (Gaitskell 1959). Although the possibility of largescale cotton cultivation had been suggested as early as 1839, Garstin proposed to use the Gezira as a wheat-producing area for the nearby Arabian market (Barnett 1977). As proposed by Garstin, the Scheme would not need water in the dry months. He did propose, however, the construction of a dam or barrage at Sennar on the Blue Nile to provide irrigation for part of the Gezira.

The Gezira plain is two hundred miles long and eighty miles across, covers an area of five million feddans and slopes gradually from south to north (Gaitskell 1959; 26). Its most outstanding feature was its monotony (Barnett $1977 ; 1)$. The erratic rainfall decreased towards the north and could not assure a crop every year. In good rain years, the cereal crops in the plain would provide sufficient harvests. In bad years, waterwheels in the river provided water for narrow strips on the banks. This erratic use of the plains resources over the years by local farmers gave the impression to the British colonizers that the plain was empty, as only very few permanent settlements could be found. Therefore, in the first decades of the twentieth century, instead of investing in a large system in Gezira, the colonial Sudanese 
Government focused on a number of smaller flood irrigation projects in areas, which did not involve the Nile, such as the Gash and Tokar deltas (Gaitskell 1959). Other projects preceding the Gezira Scheme were small-scale pump irrigation systems along the banks of the basin's rivers. These allowed the Sudanese Government and commercial growers to lay the foundation for their future co-operation in the Gezira. After World War I temporarily interrupted development efforts, in 1919 planning for the project ensued. The area to be irrigated was set at 300,000 feddans. In 1922, the contracts for constructing the dam and main canals were signed and work began. In 1925, the High Commissioner for Egypt and the Sudan, Lord Lloyd officially opened the dam.

Sennar Dam, situated about $260 \mathrm{~km}$. southwest of Khartoum on the Blue Nile, supplied canals on the left bank of the river by gravity. Originally, main canals conveyed water continuously day and night, as British irrigation engineers in India and Egypt had maintained stability of discharge in their canal systems by keeping the water flowing. The farmers were expected to handle their ration efficiently whenever it came, even at night. The first plan for Gezira irrigation was designed accordingly. But it soon became clear that Gezira tenants, who "had already accepted immense changes in daylight farming" (Gaitskell 1959; 123), were neither able nor willing to irrigate during the night. Cutting of water during the night, however, was not an option in a system the size of the Gezira. Uncontrolled water flows at night were not desired either. Engineers developed a system of weirs and pipes in the canal to address the particular water control requirements in the system (Plusquellec 1990; Gaitskell 1959). ${ }^{2}$

Balancing one field outlet against another was essential to maintain stable discharges in the canal system. Without a strict timetable the immense volume of water discharged into the main canal could not be evenly distributed over the entire network of canals. Therefore, project managers designed a detailed water distribution schedule including crop rotation. The irrigated areas were divided into blocks, varying in size as their boundaries reflected the canal system. An average block was 15,000 feddans. Each had a block inspector and two junior field officers, who already had experience from the pilot stations. A group inspector supervised six to ten blocks. Arthur Gaitskell, the first Chairman and Managing Director of the Sudan Gezira Irrigation Board, described how field personnel were "superimposed like the canal system itself on the life of the Gezira"

2 Disadvantages of this canal system were the higher costs of construction and maintenance as silting occurred more easily. In the extensions that have been realized night irrigation is practiced. 
(Gaitskell 1959; 99). ${ }^{3}$ Such a structure, linking many British inspectors so closely to the people in a factory-like organization, differed considerably from British indirect rule in India. In 1929, the irrigable area reached 527,000 feddans. Extensions carried out from the late 1920 s to the early 1950s increased the command area to around one million feddans (Gaitskell 1959).

The French too were actively involved in colonial irrigation matters in Africa, developing factory-type irrigation schemes both in West Africa (Senegal and Mali) and North Africa (Morocco, Tunisia and Algeria) (Ertsen 2007). The French engineers planned one of their most challenging irrigation projects in the Inner Delta of the Niger in Mali. Referred to as the Office du Niger, the plan sought to equip about 1,000,000 hectares in the delta with irrigation facilities. In 1932, a French public enterprise was created with the responsibility for irrigation development and settlement of the population in the area. By 1945, about 20,000 persons had 'colonized' some 22,000 hectares in two different regions of the central delta (De Wilde 1967a). Although the irrigation developments in West Africa appear to be more impressive than in the French colonies in North Africa, at least in terms of planned acreages, it was in the North African territories that the French colonizers developed their irrigation technique of concrete, raised canals put on an area in a fixed grid. These systems not only reflected colonial control over the population, but also over the landscape. A landscape of many irregular sized and shaped holdings was transformed into one with redistributed holdings of regular rectangular parcels. Although the French concrete grid can be regarded as the archetype land management, similar geometric landscapes came to epitomize the new irrigation realities in African colonies.

\section{The Mwea system, Kenya}

British engineers in Kenya also looked to expand irrigated agriculture. Taking into account the experiences in Gezira, in the late 1920s they began planning a large-scale irrigation project for the Mwea plain, a 62,000 hectare region bordered by the Thiba and Tana rivers. Mean annual rainfall in the area is about $1100 \mathrm{~mm}$, thus rain-fed agriculture is an option. By 1930, the borders of the swampy

3 Arthur Gaitskell went as a field executive to the Gezira in 1923. He also worked for the Finance Headquarters, became Chief Field Executive and Assistant Manager, and from 1945 to 1950 General Manager of Gezira. From 1950 to 1952, he was the first Chairman and Managing Director of the Sudan Gezira Irrigation Board, the organization managing the Gezira in independent Sudan. His 1959 book, Gezira: A story of development in the Sudan remains the most comprehensive discussion of the project. 
plain were inhabited by groups of people of different origins: the Mbere claimed the plain to collect honey, whereas Ndia, Gichugu and Muranga used part of the plain to graze their livestock (Diemer 1990). These groups seem to have gradually colonized the plain. Regardless of the existing production systems, the colonial government sought to promote agriculture in the area. In 1925 the government supported a private initiative to irrigate sugarcane in the plain and, four years later, the Embu District Administration (Nyeri Province, Kenya in which Mwea is located) proposed to employ instructors from neighboring Tanganyika to provide training on irrigation furrows. Although they agreed that irrigated agriculture was central to the region's development, administrators debated what crops should be grown. In 1933, the Nyeri Provincial Agricultural Office suggested the establishment of irrigated rice farms, while the District Agricultural Officer considered cotton as the most promising crop. After an attempt to grow cotton failed, the crop disappeared from the discussion (Diemer 1990).

As in many other colonies, the period directly before and after the Second World War brought new debates about the goals of colonialism, the relationship between colonizer and colonized, and which colonial policies were desirable. In Mwea, these debates centered on two options: expand the coffee estates of European settlers or develop a large-scale irrigation system similar to Gezira for cotton and rice cultivation. This second proposal won out and in 1944 the Embu Agricultural Officer included it in the draft Ten Year Development Plan. The Mwea Development and Reclamation Scheme was published in 1949. By the end of 1950, the 22-mile Mwea furrow for a pilot area was nearly complete. The government decided that rice should be cultivated on the clay soils in the plain; by 1967 , approximately 5,000 acres of the heavy clay soil grew irrigated rice. While the existing head works and main canals could irrigate 15,000 acres, the layout of earlier system units had failed to take into account mechanized land preparation. George Manig, formerly the Senior Irrigation Engineer of Kenya's National Irrigation Board in Kenya , noted in 1973 that

[I]t was soon apparent that manual field leveling and cultivation [...] could not meet the demands of sophisticated agricultural production required by the Government's income policy (Manig $1973 ; 91) .^{4}$

4 After 35 years of experience in Mozambique and Tanzania, George G. Manig joined the Public Works Department in Nairobi in 1961. He started working in Mwea in 1963 and became the Senior Irrigation Engineer of the National Irrigation Board in Kenya in 1966. 
To allow for mechanized preparation, the layout of plots was made much more regular. Plots of 100 meters by 40 meters were supplied with water through a network of canals (figure 3 ).

The development of the Mwea system was highly politicized. Anticolonial protests grew in the late 1940 s and early 1950 s, materializing in 1952 with the outbreak of the Mau Mau Revolt. One of the main issues in the protest was land ownership. When the Mau Mau Revolt started, Mwea was among the regions that witnessed some of the earliest and heaviest violence. This stemmed from conflicts over the control of land on the plain. Jon Moris, a rural sociologist who conducted research in Mwea in the late 1960s, described how further surveys on the plain in 1951 "must have been like a match tossed into a powderkeg" (Moris $1973 ;$ 59). The surveys caused a common fear among the settlers on the plain that their lands were about to be taken by the Europeans. The Mwea Scheme became one of the measures to deal with the reasons for the revolt. Officially started in 1953, the Mwea project's main purpose was to provide employment to Kikuyu who had been detained under the Mau Mau Emergency Regulations (De Wilde 1967ab; Diemer 1990). The imprisoned men had to work on the construction of the scheme. This would allow the colonial government to recoup the costs of imprisonment from the future profits of the irrigation scheme. Furthermore, by handing out plots to landless Kikuyu the government attempted, in a limited way, to respond to Mau Mau demands. ${ }^{5}$

\section{Figure 3. Impression of the Mwea irrigation scheme. Source: Chambers \& Moris 1973; annex.}

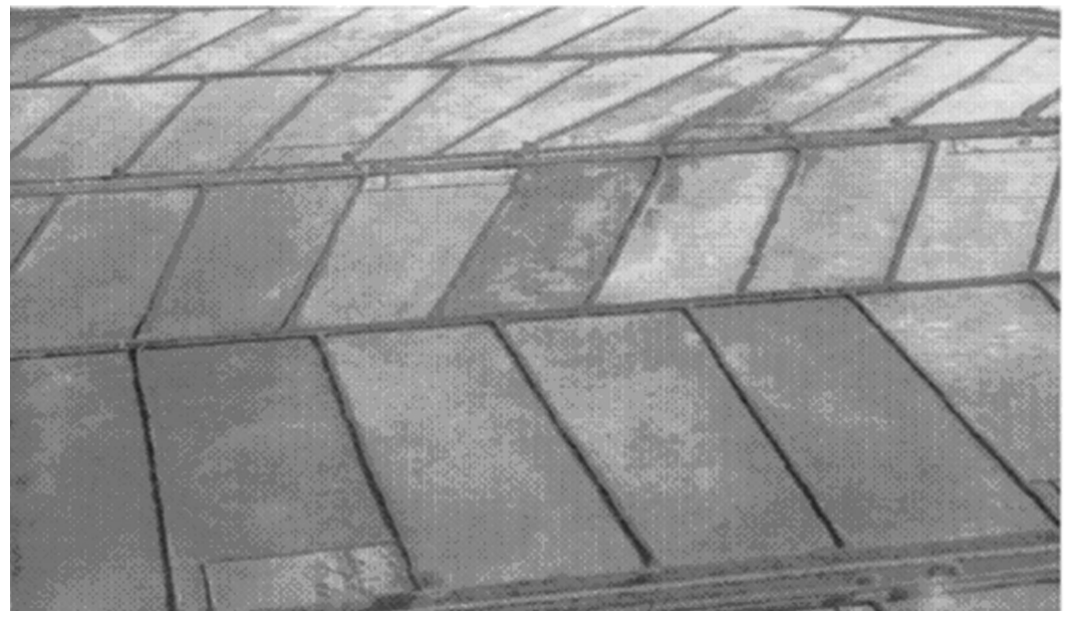

5 An in-depth discussion of Mau Mau is outside the scope of this paper. See Tabitha Kanogo, Squatters and the roots of Mau Mau (James Currey London; Heinemann, Kenya; Ohio University Press), 1987. 
The use of the Gezira's tenancy model at Mwea served short term goals. After the Mau Mau Revolt, the government needed a place to send the large number of Kikuyu detainees.

Constructing labor intensive irrigation works could provide productive work for detainees (Chambers 1973), and the irrigation system once constructed could provide settlement opportunities for landless families. In order to justify a settlement scheme, planners needed to portray the Mwea area as empty as possible. Although the area had been in use by several groups, as discussed above, the Mwea irrigation system was developed with the idea that the plain was almost empty, comparable with the idea in the Gezira (Ertsen 2006). J.J. Veen, the manager of the Mwea project from 1962 to 1966, noted how

Developing the area was facilitated by the almost total lack of population which meant that there were few families to be evicted and they were offered places as tenants (Veen 1973; 116).

Moris referred to this idea of the empty region as "one of the most enduring management myths of Mwea", as people already lived on the plain. It was certainly cheaper to consider the area as empty, as this saved the colonial government the trouble of compensating the former owners financially (Moris 1973; 36).

Administrators forced the tenants to submit to a strict management system. John C. de Wilde, the Acting Director of the Economic Staff of the International Bank for Reconstruction and Development, described how scheme management was built on the idea that both management and tenants would be working under "a fairly rigid schedule of operations" (De Wilde 1967b; 236).

Agricultural operations were not supposed nor permitted to change from the official time schedule. Farmers in one area were not allowed to change their production pattern or rhythm as this would upset land preparation or the approved irrigation schedule (De Wilde 1967b; 236-237). "Persuasion" was the principal means of getting the farmers to accept discipline, with the field assistant from the management and a head cultivator, leader of the tenants in his block, being primarily responsible for "inducing farmers to time and synchronize their operations properly" (De Wilde 1967b; 237).

From 1960 onwards, the tenants were required to subscribe to a set of regulations, which became known as the Trust Land (Irrigation) Rules. These Rules consisted of an eight-page document, which each tenant had to sign. The Rules included legislation for crop and water discipline, absenteeism, disposal of the crop, and gave the management power to take disciplinary action against tenants failing to adhere to instructions (Veen 1973). 
Tables 1 and 2 present examples of such offences, warnings issued by scheme management and termination of licenses in response. In 1976, De Wilde argued that

The types of offences which gave rise to warnings and fines indicate that management must keep up a constant pressure to get tenants to carry out their work punctually (De Wilde 1967b; 237).

Close supervision was linked to military-like structures of management, as a former manager of the Mwea system remarked: "The overall system of management is semi-military, which is necessary for the required strict control over the tenant.

This may sound rather harsh but the success of Mwea is largely attributable to the close supervision which protects the tenant from failure" (Veen 1973; 127). As demonstrated in Table 3, this strict management approach, with strong farmer guidance, was a direct copy of the Gezira system.

Table 1 Number of warnings in the Mwea system in 1970/1971. Source: Veen 1973; 125.

\begin{tabular}{|l|c|c|c|c|c|}
\hline Subject & Jul-Sep & Oct-Dec & Jan-Mar & Apr-Jun & Total \\
\hline Maintenance of holding & 56 & 140 & 8 & 68 & 272 \\
\hline Absenteeism & 17 & 42 & 1 & 23 & 83 \\
\hline $\begin{array}{l}\text { Failure to comply with } \\
\text { instructions }\end{array}$ & 100 & 85 & 23 & 25 & 233 \\
\hline $\begin{array}{l}\text { Unauthorized use of } \\
\text { irrigation water }\end{array}$ & 9 & 39 & - & 13 & 61 \\
\hline Unauthorized livestock & 3 & 2 & - & 2 & 7 \\
\hline Yield performance & - & - & - & 1 & 1 \\
\hline House construction & 11 & - & 4 & - & 15 \\
\hline Final warnings & 11 & 18 & 1 & 7 & 37 \\
\hline Total & 207 & 326 & 37 & 139 & 709 \\
\hline
\end{tabular}

Table 2. Number of license terminations between 1961 and 1970. Source: Veen 1973; 127. 


\begin{tabular}{|l|c|l|l|l|l|l|l|l|l|l|l|l|}
\hline Cause & 1961 & 1962 & 1963 & 1964 & 1965 & 1966 & 1967 & 1968 & 1969 & 1970 & Total & $\begin{array}{l}\text { Total } \\
\text { incidence (\%) }\end{array}$ \\
\hline $\begin{array}{l}\text { Imprison-ment } \\
\text { for more than 6 months }\end{array}$ & 3 & 1 & - & - & 1 & 1 & 4 & 7 & - & 1 & 18 & 16.4 \\
\hline Bad husbandry & 3 & 1 & 8 & 3 & 5 & 4 & 9 & 4 & 7 & 9 & 53 & 48.2 \\
\hline Desertion & - & 3 & - & 2 & 6 & 5 & 5 & 7 & 5 & 6 & 39 & 35.4 \\
\hline Yearly total & 6 & 5 & 8 & 5 & 12 & 10 & 18 & 18 & 12 & 16 & 110 & 100 \\
\hline Total & 0.48 & 0.40 & 0.60 & 0.37 & 0.82 & 0.63 & 0.95 & 0.86 & 0.58 & 0.68 & 0.68 & \\
\hline
\end{tabular}

Mwea has been regarded as a successful example of post-colonial irrigation development and has served as source of inspiration for other irrigation systems in Africa. In 1973, Robert Chambers and Jon Moris edited a book on the project. ${ }^{6}$ In their introduction, they argue for the further study of the project as it remains an example for different development experts to emulate:

To the technical assistance expert, the Scheme offers a model of a highly successful production system that combines strongly centralised management with the attainment of relatively high rice yields by over two thousand tenant farmers year after year. [...] To the engineer, the entirely gravity-fed system for irrigation on Mwea is a remarkable achievement, but it also raises questions about the extent to which the Scheme's system can be replicated in other, less favourable environments. To the policy-maker, the Scheme is significant because it has epitomised the costs and benefits of a particular philosophy of agrarian development, one which puts primacy on the realisation of technical objectives and which assumes that the other benefits of development will come automatically in time as the result of the raised incomes which the Scheme makes possible (Chambers \& Moris 1973; 6).

6 Robert Chambers served as district officer and a lecturer of public administration at the Kenya Institute of Administration between 1958 and 1964. From 1964 to 1966 he was research officer of the East African Staff College. 
Table 3. Translation of key principles of Gezira to Mwea. Source: Adapted from Gaitskell (1959) and Chambers and Moris (1973).

\begin{tabular}{|c|c|c|}
\hline & Gezira & Mwea \\
\hline General approach & $\begin{array}{l}\text { A policy of control and } \\
\text { help: control to ensure } \\
\text { adherence to a productive } \\
\text { system, help to make } \\
\text { adherence at each point } \\
\text { as easy as possible }\end{array}$ & $\begin{array}{l}\text { All growers are licensed by } \\
\text { the Scheme Management, } \\
\text { renewably annually, and are } \\
\text { subject to prosecution and } \\
\text { eventual dismissal for failure } \\
\text { to comply with Management } \\
\text { orders }\end{array}$ \\
\hline Land use and farming & $\begin{array}{l}\text { A planned system of } \\
\text { land usage, based on } \\
\text { scientific experiment } \\
\text { and practical experience, } \\
\text { and protected by a } \\
\text { tenancy agreement }\end{array}$ & $\begin{array}{l}\text { The Settlement handles only } \\
\text { one crop, irrigated paddy, } \\
\text { whose essential operations } \\
\text { are all vertically interlinked } \\
\text { within the Scheme and } \\
\text { Board organization }\end{array}$ \\
\hline Field staff & $\begin{array}{l}\text { Efficient, active and } \\
\text { honest management staff, } \\
\text { whose conditions of } \\
\text { service offer, as far as } \\
\text { possible, a long-term } \\
\text { interest in and sympathy } \\
\text { with the project. }\end{array}$ & $\begin{array}{l}\text { The ratio of field staff to } \\
\text { tenants is high, and there } \\
\text { are parallel organizational } \\
\text { hierarchies responsible for } \\
\text { water control and husbandry } \\
\text { advice }\end{array}$ \\
\hline Tenancy arrangements & $\begin{array}{l}\text { Legislation to protect } \\
\text { the tenancy against } \\
\text { subdivision, sub-letting, } \\
\text { mortgage or foreclosure } \\
\text { except by the manage- } \\
\text { ment for a breach of } \\
\text { the tenancy agreement }\end{array}$ & $\begin{array}{l}\text { Each tenant receives the } \\
\text { right to four one-acre } \\
\text { irrigation units on entry, and } \\
\text { is not eligible to expand his } \\
\text { holding (by the addition of } \\
\text { irregular sized 'extra fields') } \\
\text { unless it has been well- } \\
\text { managed }\end{array}$ \\
\hline
\end{tabular}

According to Chambers and Moris, the Mwea experience led development specialists to reconsider what development is and how it might occur under alternative administrative structures. For those seeking to evaluate the success of the system in terms of production and tenant income generation, Mwea does promise many interesting features for many different people. Chambers and Moris present what they consider the key ingredient of Mwea's success: The Mwea system was a highly sophisticated instrument of production control, including proven decision rules covering all aspects of production and accompanied by a corpus of managerial myths (Chambers \& Moris 1973; 7). The influence of the book is still reflected in a 1986 Food and Agriculture Organization (FAO) report which discusses the Mwea scheme as an example of a highly supervised project (Sagardoy et al 1986). The validity of the Mwea model is only partially acknowledged in the report. In the first 10-15 years of its operation, the system was described as very successful, given the increased production and higher farmer incomes. However, the report feared that strong mechanisms for centralized control in the initial stages might not be 
able to adapt to changing circumstances, with potential social and economic stagnation as a result.

\section{The Kano River Project, Nigeria}

With African independence in the late 1950s and early 1960s came a strong belief in the capacity of development administrations to modernize agriculture through irrigation settlement schemes (Bolding 2004; 11). In the late 1960s and early 1970s, the newly independent Nigerian government sought to develop three irrigation projects in Northern Nigeria. Each project was designed and implemented by different foreign consultants: the Kano River Project (KRP) including the Tiga reservoir by Dutch consultants, the Sokoto River Project by Italian consultants, and the South Lake Chad Project by British consultants. All of these projects sought to modernize the existing agricultural systems. As Forrest explains:

A further attraction of irrigation lies in the symbolic appeal of a modern, transformed agriculture, associated with a reorganisation of tenure, dictation of cropping patterns, resettlement, planners, state bureaucrats and foreign experts (Forrest 1981; 241).

In addition to facilitating this transformation, the projects attempted to (1) increase the production of wheat so as to reduce imports and save foreign exchange and (2) increase productivity and improve rural living standards (Baker 1989; 38). Planners believed that the resettling of farmers into larger production units would allow for the provision of services such as schools, markets and hospitals, and thus improve rural welfare (Wallace 1979a; 243).

Dutch engineers took the lead on planning for the irrigation of the Kano plain. Part of the larger Hadejia Jama'ara river basin, the Kano river basin has a total area of approximately 3000 square miles. The topography is flat to gently sloping, with slopes of arable land being between zero and two percent. Rainfall is highest during summer (between May and September), with a peak in August. Average rainfall is about $860 \mathrm{~mm}$ per year, but there is considerable variation over the years. Rainfall is discharged through numerous natural drainage channels. During the rainy season farmers grew crops like sorghum, groundnuts and cowpea.

Under the umbrella of NEDECO, a cooperative organization for Dutch engineering firms who had united in 1951 after the independence of Indonesia, Dutch engineers were strongly involved in the actual planning and implementation of the Kano River Project. For the Dutch engineers and government development aid was an opportunity to employ those engineers who had worked in the Netherlands East Indies before its independence and maintain the former East Indian 
specializations at Dutch universities. The Dutch irrigation professionals emphasized the need to broaden the perspective of irrigation engineering from the East Indies to all tropical regions, and even to the Netherlands. They distinguished between distribution of water to farmers with reasonably-sized properties, for example in the U.S.A., South Africa and Australia, and distribution to groups of smallholder farmers, which was mostly found in the tropics (Eysvoogel 1950; 341).

These tropical regions were defined as equal to Java, the East Indian main island. The Dutch irrigation sector stated that Dutch colonial engineers had thoroughly studied and defined the principles which had to be applied when designing and constructing irrigation systems in 'tropical regions'. In this way, the East Indian irrigation concept, as discussed in Ertsen (2006a \& 2007), was made applicable to other regions.

Armed with these ideas and confident about their applicability, the Dutch engineers drafted feasibility studies, made the designs and advised on management procedures for Kano. In October 1969, the Kano State Government commissioned NEDECO to undertake a feasibility study for the KRP. In a 1968 report, the FAO had suggested to copy the Mwea structure completely, including the tenancy model.

The NEDECO engineers, however, considered land tenure as important as they believed it would stimulate farmers to invest in agricultural production and land protection measures (NEDECO 1970). NEDECO also reported that the costs could be fairly well estimated, but that the profits due to increase in production could not be predicted easily. After all, these depended on the way individual farmers would use and profit from the newly created irrigation opportunities (NEDECO 1970; 123). To ensure proper use and thus profit, NEDECO suggested building an organization "to have the farmers advised and guided in all phases of production" (NEDECO $1970 ; 123)$. Although the report suggested that stronger control was needed for irrigation water operation and management compared to providing inputs and marketing opportunities, these four elements were seen as closely interrelated. Therefore, the elements formed one 'package deal', with the need to develop one single authority capable of organizing and co-coordinating the supporting activities (NEDECO 1970; 123).

Project management in Northern Nigeria was to have full control over the crop production system, including marketing and input supply. NEDECO stipulated that tenant farmers be selected for their working ability and their "calculated capacity to adapt the severe discipline of two crops per year irrigation farming" (Strong \& Paton 1968; 63; quoted in Andrae \& Beckman 1985; 114). Disciplining farmers would directly influence project profitability. 
In 1974 NEDECO wrote an additional short report on the management needs of the Kano system, stressing that the canal system required proper operation and maintenance. Farmers should be fully conversant with irrigation technologies and cultivating irrigated crops. Inputs such as fertilizers, insecticides, agricultural machinery and credit facilities should be made available. Marketing of agricultural production should be organized (NEDECO 1974; 1-2).

NEDECO concluded that the complex scope of the project could potentially be problematic given the scarcity of skilled and experienced manpower. It therefore recommended developing central project management. All decisions on water control, water distribution, and most of those on agricultural aspects were the responsibility of the project management, at least in the initial years (NEDECO 1974; 6). Further nuance was brought in, as management did aim at participation of the farmers by defining the areas of decisionmaking for farmers and management. The areas included crop choice, cropping pattern and rotation, water management, mechanization, input provision and marketing of crops (NEDECO 1974; 6).

These nuances were needed. The Kano planning process proved rather complex, particularly as land rights and ownership played a role. In the 1970 report, NEDECO had indicated that communal ownership was an important constraint to crop production, as a farmer would be less inclined to take measures for improving agriculture on land he did not own. The KRP had to establish new land tenure patterns through a process of land consolidation. The planning process had to take into account existing social structures, land tenure and claims to land. A particularly important and rather difficult aspect of developing the Kano area was that the area was densely populated. It was not an 'empty' area like Mwea (which was less populated than Kano). Imposing new tenure arrangements would not be simple. "Resistance was foreseen but it was assumed that the projects would be given adequate powers to deal with it" (Andrae \& Beckman 1985; 113).

NEDECO consultants believed that to control the farmer there was the need to control the land (Wallace 1981; 287). In 1983, however, an expert concluded almost with regret that

[E]xperiences both at Bakolori and the Kano River project [...], which has been in operation about two years longer than Bakolori, indicate that where a policy of not acquiring the Rights of Occupancy but rather re-allocating the land back to the farmers, has been followed, then the resulting lack of control over the land is a very serious impediment to operating the schemes at their optimum level (Bird 1983; 79).

This did not only impact the Kano project. Siann, another irrigation 
expert, noted the "disquieting evidence" that examining Bacita Sugar Estates and South Chad Projects showed that

Nigerian society has as yet not become attuned to the discipline imposed by an irrigation-assisted system of farming (Siann 1983; 91).

Thus, although the project management was based on similar production assumptions as the Mwea system, it could never develop the underlying management strength that Mwea had. The production system was based on modern irrigation infrastructure and central facilities to provide input and arrange the marketing of crops. The farmers were expected to adapt to this production system, but they were not to be forced. Instead, "full level extension workers taught farmers how to make the most of irrigation technology". Farmers were also

instructed in the use of new and improved seed, fertlisers, insecticides and pesticides, as well as other inputs, in the right quantities and at the right time in conjunction with irrigation water (Baker 1989; 38; emphasis added).

Thus, in terms of organization, the Kano system never was as discipline oriented as the Mwea system. The inability to "discipline non-cooperative farmers" frustrated management (Andrae \& Beckman $1985 ; 114)$. These frustrations are illustrated by the comments of project officials. One official remarked in 1977 that

[Slome farmers cooperate but it is not satisfactory because we have to ask farmers, not tell them what to do (quoted in Wallace 1981; 287; (emphasis in original).

Compared to Kano, however,

$[\mathrm{T}]$ he Scheme at Lake Chad is easier because they bring people there and they have a yearly contract with rules and regulations and the farmer can be thrown off the Scheme (quoted in Wallace 1981; 287).

It is very likely that these officials agreed with the proposal of NEDECO to develop new legislation enabling stronger control over land reallocation and consolidation.

One may question whether earlier irrigation interventions in Nigeria were taken into account. One critical account of the optimistic planning of the irrigation system even refers to the unrealistic prospects to realize "a Gezira scheme of irrigated wheat competing with imports seems a very remote prospect." (Wallace 1979b; 5; original quote from Wells 1974). Whatever the case, the issue of control over farmer behavior through extended control over land had been clearly discovered before. The British had started with interventions and programs for irrigation in Nigeria after the Second World War. Modernization of agriculture became a major goal, especially the 
introduction of mechanization, which was seen as a necessity for the peasant economy of West Africa (Forrest 1981; 233). Large schemes were proposed, particularly the Niger Agricultural Project.

This settlement scheme did not work out as planned, however, as preliminary investigations were insufficient and labor inputs required proved to be unrealistic. A main factor of the failure was that settlers

... resented an authoritarian management which told them where to live, where to farm, what to grow and when to perform various agricultural operations (Forrest 1981; 233).

Similar 'lessons' had also been learned in Kwarre, a pre-Second World War colonial irrigation scheme, in which a lack of control over land and thus peasant behavior by scheme management were seen as hampering full-scale development (Palmer-Jones 1981). Taking into account these experiences from the start of the irrigation activities would have suggested that the Gezira- and Mwea-induced approachstrong central management of a tenant-based project predicated on the assumption of an empty area-might have been less appropriate for Northern Nigeria.

\section{Mwea, Gezira, Kano and the international arena}

The case of the Gezira, Mwea, and Kano projects demonstrates how irrigation development activities did not end after the colonial territories attained independence. As described above, the distinction between the colonial and the post-colonial irrigation programs is less abrupt than the political transition from colony to independent state. Within the independent states, international consultants continued the colonial approaches. For European engineers and development consultants, colonial knowledge became exportable through development aid. Many international irrigation specialists have recognized the Mwea system as a model to follow in rural development. The project was based on the premise that

[T] he population must be reorganised 'to meet the requirements of efficient irrigated agriculture' (Wallace 1979a; 243; original quote from NEDECO 1976).

Most irrigation projects would have failed in Africa for lack of centralized management. When such management lacked, farmers could not be provided with the services needed to secure their social well-being (Veen 1973; 124). The Gezira case had shown how control of land was used to force farmers to produce cotton, rather than food for consumption and sale. The economist Judith Heyer has shown how

This 'transformation' approach, in the form of large-scale settlement, irrigation and outgrower schemes, involves direct control of peasant production by external agencies (Heyer et al 1981; 6). 
With forced reorganization out of the question, however, modern approaches for centralized management in rural development programs offer an alternative for direct coercion. Instead, modern management provides a package of inputs and welfare services, which seek to stimulate increased participation in the project and agricultural production (Heyer et al 1981; 8).

Project managers recognized that development projects, especially resettlement programs, caused difficult changes for rural families. Relocation led to changed social ties, adaptation to a different climate and environment, and the need to learn new methods of production and accept -a "degree of discipline under the supervision of a strange management" (De Wilde 1967a; 63). People tend to take on these challenges only if they believe that the new way of life offered would actually increase their security and income. Therefore, project managers used the promise of increased income to attract farmers to irrigation projects. The new spirit of development aid, in which technical and managerial assistance was stripped from its colonial roots, made it possible to re-evaluate the Gezira and Mwea systems from this new economic perspective. For example, in 1973 Chambers and Moris acknowledged that many settlement schemes in tropical Africa failed because economic benefits were not enough to attract settlers. However, according to De Wilde, the Gezira scheme managed to provide settlers with an income superior to any of the neighboring areas. This would have been an important factor in recruiting sufficient settlers. Similarly, De Wilde believed that Mwea would have given settlers incomes high enough to make them put up with an unfamiliar village pattern of settlement (De Wilde 1967a; 63-64).

Through a combination of control and assistance African farmers were to be guided in productive activities. Rural development projects were used as an important instrument to make farmers adapt themselves to the external development requirements, including producing for markets and conforming to strict water management regulations. With fewer options for strict control, however, post-colonial schemes had to focus on building support structures for farmers.

A certain translation of colonial coercion and force towards extension and training filled the gap. Forced production schemes were translated into extension programs to support the African peasant who "[...] was considered ignorant, uneducated and in much need of "modernisation" (Baker 1989; 41). Irrigation settlement projects had a key role to play in realizing this goal. But project managers encountered various problems in achieving this transformation. Many settlers had a low educational level, practically no financial resources, and, occasionally, no agricultural experience. Project staff did not view the settlers as prepared to independently perform the required tasks. They needed to be guided through the process of 
transitioning from subsistence production to commercial agriculture.

The key to the success of settlement projects was found in strong management, with government officials responsible for overseeing the more complicated, technical aspects of agricultural production. In this system, farmers would only be given simple and straightforward tasks which they could carry out with their own means. Over time, more complicated tasks could be transferred to farmers (Sagardoy et al 1986).

Although the vision driving post-colonial irrigation development promoted the ideal that agricultural production would be pursued by independent farmers responding to market incentives rather than colonial force, the call for strict management did not disappear. According to several experts, the desired market incentives were not well developed in African rural societies. Although African farmers did respond to prices of products, they were not seen as always behaving as the desired homo economicus. De Wilde explains this perspective:

Confronted by alternative opportunities Africans often display a keen ability to chose the least burdensome (in terms of labor) way of attaining the income they want, or, to put it in other words, the ones likely to give them the highest return for the amount of work they are willing to do (De Wilde 1967a; 63).

One could argue that such an approach to labor versus income is rather economical. However, in the African context, development agencies associated this farmer approach with farmer ignorance. With farmers being unaware of their need for modernization and being unable to raise production through such modernization, raising total production required rather strong central management, responsible for many tasks, including maintenance, operation and purchase of machinery, managing the irrigation system, organizing supplies, organizing farmers, and regulating marketing activities. The effectiveness of these operations was to be ensured by allowing the management to enjoy "a considerable measure of autonomy" (De Wilde 1967b; 241). Apparently, the management institutions that had to assist farmers through strict control, should themselves not be under too strict control by higher authorities. The message was clear: Everybody needs to be controlled, but some need to be controlled more than others.

\section{Civilization is order: concluding remarks}

Elspeth Huxley did know what the new earth shaped by colonial policies would look like. Not only did she know British colonial policies in Africa very well, she also visited many material consequences of these policies. Her book on her visits to several settlement schemes in Africa from 1960 clearly shows her admiration 
for colonial policy:

From the air one sees that civilization is order: a pattern imposed upon a shaggy landscape. To some extent it is simply straight lines. [...] we came suddenly to a patch of squares, as if we had an aerial view of the Red Queen's chess-board. The landscape had been laid out with a ruler, it was patterned with black and green rectangles, streaked by lines and dotted with neat toy compounds. [...] This was the Mwea-Teberre irrigation scheme, lying on the plains south-east of Mt. Kenya. (Huxley 1960; 204).

This paper has explored how the rules of colonial chess influenced post-colonial irrigation development. It has not attempted to determine the success or failure of these approaches. After all, success or failure has much to do with the perceptions of with an interest in success or failure. What the paper has demonstrated is how the perceptions of colonial managers, policy makers and engineers on proper irrigation development continued to shape policies for postcolonial irrigation development in Africa. Recently Mwea farmers and human rights organizations in Kenya have shown that these original colonial principles are not untouchable anymore and need to be (and in many cases fortunately are already) replaced with management approaches more consistent with modern society (see for example Kenya Human Rights Commission 2000). Colonial perceptions of an 'empty' Africa were wrong at the start, but both the Kano and Mwea projects have shown that its modern equivalents are no longer tenable either. The Red Queen has changed the rules of chess.

\section{References}

Anderson, D. 2002. Eroding the commons: The politics of ecology in Baringo, Kenya, 1890-1963. Oxford: James Currey; Nairobi: E.A.E.P.; Athens, Ohio: Ohio University Press.

Andrae, G. \& Beckman B. 1985. The wheat trap: Bread and underdevelopment in Nigeria. London: Zed Books; Totowa, New Jersey: Scandinavian Institute of African Studies.

Baker, K.M. 1989. Agricultural change in Nigeria. London: John Murray.

Barnett, T. 1977. The Gezira Scheme: An illusion of development. London: F. Cass.

Bassett, T.J. and Crummey, D. (Eds.). 2003. African savannas: Global narratives and local knowledge of environmental change. Oxford: James Curry; Portsmouth, New Hampshire: Heinemann.

Bird, A.C. 1983. The land issue in large scale irrigation projects, some problems from Northern Nigeria. In W.M. Adams \& A.T. Grove 
(Eds.), Irrigation in tropical Africa: Problems and problem solving. Cambridgeshire: African Studies Center, Cambridge University.

Bolding, A. 2004. In hot water: A study on sociotechnical intervention models and practices of water use in smallholder agriculture, Nyanyadzi catchment, Zimbabwe (Doctoral dissertation, Wageningen University, 2004).

Bolding, A., Mollinga P.P., \& Van Straaten K. 1995. Modules for modernisation: Colonial irrigation in India and the technological dimension of agrarian change, Journal of Development Studies 31(6): 805-844.

Brouwer, R. 1987. Design and application of automatic check gate for tertiary turnouts. 13th International Congress on Irrigation and Drainage, International Commission on Irrigation and Drainage. Rabat, Morocco: 671-683.

Carroll, L. 1993. The complete illustrated works of Lewis Carroll. London: Chancellor Press.

Chambers, R. 1973. The history of the scheme. In R. Chambers and J. Moris (Eds.), Mwea, an irrigated rice settlement in Kenya. München: Weltforum Verlag.

Davis, D.K. 2007. Resurrecting the granary of Rome: Environmental history and French expansion in North Africa. Athens, Ohio: Ohio University Press.

De Wilde, J.C. 1967a. Experiences with agricultural development in tropical Africa. Vol I: The synthesis. Baltimore, Maryland: Johns Hopkins Press.

De Wilde, J.C. 1967b. Experiences with agricultural development in tropical Africa. Vol II: The case studies. Baltimore, Maryland: Johns Hopkins Press.

Diemer, G. 1990. Irrigatie in Afrika. Boeren en ingenieurs, techniek en kultuur. Amsterdam: Thesis Publishers.

Ertsen, M.W. 2007. The development of irrigation design schools or how history structures human action, Irrigation and Drainage 56(2): 1-19.

Ertsen, M.W. 2006a. Aspects of irrigation development in the Netherlands East Indies, TD: Journal for Transdisciplinary Research in Southern Africa 2(1): 47-72.

Ertsen, M.W. 2006b. Colonial irrigation: Myths of emptiness, Landscape Research 31(2): 147-168.

Forrest, T. 1981. Agricultural policies in Nigeria, 1900-78. In J. Heyer J., P. Roberts \& G. Williams (Eds.), Rural development in tropical 
Africa. New York: St. Martin's Press.

Gaitskell, A. 1959. Gezira: A story of development in the Sudan. London: Faber \& Faber.

Heyer, J., Roberts, P. \& Williams, G. 1981. Rural development. In J. Heyer, P. Roberts, and G. Williams (Eds.), Rural development in tropical Africa. New York: St. Martin's Press.

Hodge, J.M. 2007. Triumph of the expert: Agrarian doctrines of development and the legacies of British colonialism. Athens, Ohio: Ohio University Press.

Huxley, E.J.G. 1960. A new earth: an experiment in colonialism. London : Chatto \& Windus.

Kenya Human Rights Commission. 2000. Dying to be free: the struggle for rights in Mwea, Nairobi, Kenya.

Manig, G.G. 1973. Engineering aspects and water control. In R. Chambers and J. Moris (Eds.), Mwea, an irrigated rice settlement in Kenya. München: Weltforum Verlag.

Moris, J. 1973. The Mwea environment. In R. Chambers and J. Moris (Eds.), Mwea, an irrigated rice settlement in Kenya. München: Weltforum Verlag.

Moris, J. \& Chambers, R. 1973. Mwea in perspective. In R. Chambers and $\mathrm{J}$. Moris (Eds.), Mwea, an irrigated rice settlement in Kenya. München: Weltforum Verlag.

NEDECO. 1970. Kano River Project feasibility study, Amsterdam.

NEDECO. 1974. Some considerations and recommendations on the management of the Kano River Project, Amsterdam.

Palmer-Jones, R.W. 1981. How not to learn from pilot irrigation projects: the Nigerian experience, Water Supply and Management 5: 81-105.

Picon, A. 2000. Technological traditions and national identities: A comparison between France and Great Britain during the XIXth century. In E. Nicolaidis \& K. Chatzis (Eds.). Science, technology and the 19th century state. Athens, Greece: Institut de Recherches Neohelleniques.

Picon, A. 2004. Engineers and engineering history: problems and perspectives, History and Technology 20(4): 421-436.

Plusquellec, H. 1990. The Gezira irrigation scheme in Sudan: Objectives, design, and performance. World Bank Technical Paper, No. 120, Washington, D.C.

Poncet, J. 1961. La colonization et l'agriculture européennes en Tunisie 
depuis 1881. Paris: Mouton.

Préfol P. 1986. Prodige de l'irrigation au Maroc: Le développement exemplaire du TADLA 1936-1985. Paris : Nouvelle Editions Latines.

Sagardoy, J.A., Bottrall, A. \& Uittenbogaard, G.O. 1986. Organization, operation and maintenance of irrigation schemes. Food and Agriculture Organization Irrigation and Drainage Paper No. 40, Rome.

Siann, J.M. 1983. Labour constraints in the implementation of irrigation projects. In W.M. Adams \& A.T. Grove (Eds.), Irrigation in tropical Africa: Problems and problem solving. Cambridgeshire: African Studies Center, Cambridge University.

Spitz, G. 1949. Sansanding: Les irrigations du Niger. Paris: Société d'Etitions Géographiques, Maritimes \& Coloniales.

Stone, I. 1984. Canal Irrigation in British India: Perspectives on technological change in a peasant society. Cambridgeshire/New York: Cambridge University Press.

Strong, T.H. \& Paton, P. 1968. Economic appraisal and analysis of requirements for development of the Talata Mafara area, Sokoto Rima Drainage Basin, United Nations Development Program \& Food and Agriculture Organization, Rome.

Swearingen, W.D. 1984. In search of the granary of Rome: Irrigation and agricultural development in Morocco, 1912-1982 (Doctoral dissertation, University of Texas, Austin, Texas, 1984).

Thornton, D.S. 1966. Contrasting policies in irrigation development, Sudan and India, University of Reading, Department of Agricultural Economics, Development Studies, No 1.

Tropp, J.A. 2006. Natures of colonial change: Environmental relations in the making of the Transkei. Athens, Ohio: Ohio University Press.

Ubels, J. and Horst, L. (Eds.). 1993. Irrigation design in Africa: Towards an interactive method, Technical Center for Agricultural and Rural Cooperation, Ede, the Netherlands.

Van Beusekom, M.M. 1989. Colonial rural development: French policy and African response at the Office du Niger, Soudan Français (Mali), 1920-1960 (Doctoral dissertation, Johns Hopkins University, Baltimore, Maryland, 1989).

Van Beusekom, M.M. 2002. Negotiating development: African farmers and colonial experts at the Office du Niger, 1920-1960. Portsmouth, New Hampshire: Heinemann. 
Van Halsema, G.E. 2002. Trial and re-trial; The evolution of irrigation modernization in NWFP, Pakistan (Doctoral dissertation, Wageningen University, the Netherlands, 2002).

Veen, J.J. 1973. The production system. In R. Chambers and J. Moris (Eds.), Mwea, an irrigated rice settlement in Kenya. München: Weltforum Verlag.

Wallace, T. 1981. The Kano River Project, Nigeria: The impact of an irrigation scheme on productivity and welfare. In J. Heyer, P. Roberts, and G. Williams (Eds.), Rural development in tropical Africa. New York: St. Martin's Press.

Wallace, T. 1979a. The impact of a large-scale irrigation scheme on two wards in a small town in Kano state, Nigeria: Its implications for rural development. In A. Southall (Ed.), Small urban centers in rural development in Africa. Madison: African Studies Center, University of Wisconsin.

Wallace, T. 1979b. Rural development through irrigation: Studies in a town on the Kano River Project, Ahmadu Bello University, Centre for Social \& Economic Research, Research Report No. 3.

Wells, J.C. 1974. Agriculture policy and economic growth in Nigeria, 1962-8. Ibadan, Nigeria: NISER

Widgren, M. \& Sutton, J.E.G. (Eds.). 2004. Islands of intensive agriculture in Eastern Africa: Past \& present. London: British Institute in Eastern Africa; Athens, Ohio: Ohio University Press. 